\title{
Pojok Digital: Upaya untuk Meningkatkan Motivasi Belajar dan Pengenalan Literasi Baru pada Siswa SD Negeri 2 Pujiharjo
}

\author{
Hasminar Rachman Fidiastuti ${ }^{1}$, Chandra Adi Prabowo ${ }^{2}$, Hanif Fikri Bariska ${ }^{3}$ \\ ${ }^{1,2}$ Pendidikan Biologi, ${ }^{3}$ Pendidikan Guru Sekolah Dasar \\ ${ }^{1,2,3}$ Fakultas Ilmu Pendidikan, Universitas Tribhuwana Tunggadewi, Jalan Telaga Warna Blok C Malang \\ E-mail : indo.hasminar@gmail.com. 085649975311
}

\begin{abstract}
ABSTRAK
Memasuki era revolusi industri 4.0, penguasaan keterampilan literasi berupa membaca, menulis, dan berhitung pada siswa tidak lagi cukup untuk memenuhi modal dasar berkiprah di masyarakat, sehingga diperlukan adanya tambahan literasi, berupa literasi baru, yang meliputi literasi data, literasi teknologi, dan literasi manusia untuk menghadapi era disrupsi inovasi. Pendidik dalam masa ini, dihadapkan pada kondisi siswa yang termasuk dalam klasifikasi generasi Z, yang ditandai dengan kemunculan generasi yang berkembang dalam era komputerisasi serta dukungan koneksi internet yang kuat dan tak berbatas. Kondisi tersebut mengharuskan pendidik memiliki strategi dan inovasi dalam memperkenalkan pembelajaran berbasis teknologi digital. SD Negeri 2 Pujiharjo masih kesulitan dalam mengembangkan proses belajar dan pembelajaran yang terjadi pada siswa. Minimnya fasilitas yang dimiliki oleh sekolah yang terletak di Desa Pujiharjo, Kecamatan Tirtoyudo, Kabupaten Malang ini membuat literasi siswa menjadi terbatas dan motivasi belajar siswa tergolong rendah. Pojok digital merupakan sebuah program pengabdian kepada masyarakat yang bertujuan untuk meningkatkan motivasi belajar dan literasi baru, baik bagi guru maupun siswa. Hasil dari program kemitraan ini telah meningkatkan motivasi belajar sebesar $30 \%$ dan literasi baru sebesar 35\% pada siswa SD Negeri 2 Pujiharjo.
\end{abstract}

Kata kunci : revolusi industri; pembelajaran digital; literasi baru

\begin{abstract}
Entering the era of the industrial revolution 4.0, mastering literacy skills in the form of reading, writing, and arithmetic to students is no longer sufficient to meet the basic capital to take part in society, so that additional literacy is needed, in the form of data literacy, technological literacy, and human literacy to face the era of innovation disruption. Educators in this period, faced with the condition of students who are included in the classification of generation $Z$, which is characterized by the emergence of a generation that developed in the era of computerization and the support of a strong and unlimited internet connection. These conditions require educators to have a strategy and innovation in introducing digital technology-based learning. Public Elementary School 2 Pujiharjo still has difficulties in developing the learning and learning processes that occur in students. The lack of facilities owned by schools located in the village of Pujiharjo, Tirtoyudo sub-district, Malang district has made student literacy limited and student motivation is low. Efforts to compile digital corners provide improved skills, both for teachers and students. The results of this partnership program have improved students' mastery of skills in the use of digital technology in learning. The challenge faced in this empowerment program is the sustainability of schools in operational management so that the results obtained are more optimal. The effort taken is to increase teacher managerial skills in operational management and develop operational management standards.
\end{abstract}




\section{PENDAHULUAN}

Memasuki era revolusi industri, terdapat perubahan signifikan yang dirasakan terutama dalam bidang pendidikan. Secara simultan, sebagai pendidik maka kewajiban kita adalah memperkokoh penguatan literasi baru yang sinergis dengan penguasaan kompetensi bidang keilmuan dan keahlian pada siswa [Fitriani \& Iksan. 2019]. Literasi merupakan kemampuan siswa untuk membaca dalam pengertian secara harfiah, maupun membaca kejadian yang sedang berlangsung. Dewasa ini, kegiatan membaca tidak hanya dilakukan dengan metode kontemporer, seperti membeli buku atau pergi ke perpustakaan. Membaca dapat dilakukan dengan berbekal aplikasi tertentu sehingga dapat diakses dengan mudah kapanpun dan dimanapun.

Teknologi dan era komputerisasi memudahkan kegiatan literasi, sehingga big data dapat diakses dengan mudah oleh siswa. Big data merupakan kumpulan informasi yang tak terbatas. Untuk menunjang keefektifan penggunaan big data, maka tugas pendidik adalah menyiapkan siswa agar memiliki kemampuan dalam menggunakan dan memanfaatkan big data (teknologi) dengan baik. Teknologi dapat dimanfaatkan untuk memperoleh informasi dan ilmu pengetahuan yang lebih banyak dan bermanfaat [Sholikha].

Analisis pasar kerja saat ini membutuhkan berbagai kombinasi skill, sehingga dibutuhkan relevansi antara bidang pendidikan dan pekerjaan, yang disesuaikan dengan perkembangan IPTEK dengan tetap mempertahankan aspek humanities [Intan, 2018]. Era disrupsi mengharuskan masyarakat memiliki kemampuan 'melek literasi'. Dalam kajian literasi, kategori masyarakat digolongkan ke dalam tiga bagian, yaitu 1) praliterasi, 2) literasi, dan 3) pascaliterasi. Terdapat konsep yang harus dilakukan dalam memperkenalkan literasi baru kepada siswa, pertama bahwa literasi data memfokuskan pemahaman dalam membaca data, menulis data, mengarsipkan [Ahmadi, 2017] serta menuliskan kembali data yang sesuai dengan kebutuhan siswa. Tantangan untuk memulai memperkenalkan literasi baru di SD Negeri 2 Pujiharjo bukanlah hal yang mudah dan instan, sehingga perlu upaya pendampingan. Hal ini dilakukan, agar setelah kegiatan pendampingan selesai, embrio semangat dalam pengembangan keterampilan untuk memahami literasi baru, tetap berjalan dan semakin berkembang nantinya.

Target khusus yang ingin dicapai adalah peningkatan fasilitas sekolah melalui fasilitas pojok digital. Hal ini diharapkan menjadi wawasan bagi sekolah mitra agar dapat mengembangkan pojok digital sebagai sarana baru sekolah dalam penyelenggaraan proses belajar yang melibatkan unsur teknologi.

\section{METODE KEGIATAN}

Metode pelaksanaan program kemitraan masyarakat dilakukan melalui 1) penyusunan desain pojok digital, 2) menyusun manajemen operasional penyelenggaraan pojok digital, 3) 
pengukuran motivasi belajar dan literasi baru siswa setelah adanya pojok digital. Peningkatan Motivasi belajar dan literasi baru diukur melalui angket dan observasi, 4) pendampingan serta fasilitasi keberlangsungan pojok digital. Kegiatan pendampingan secara langsung dilakukan dengan tujuan untuk menginisiasi guru agar dapat menyusun SOP dalam kegiatan manajemen operasional untuk tujuan keberlangsungan pojok digital.

\section{KARYA UTAMA}

Hasil dari kegiatan program kemitraan masyarakat di sekolah mitra SD Negeri 2 Pujiharjo yaitu :

1. Desain ruangan pojok digital serta konten pembelajaran di dalamnya. Desain ruangan ini awalnya merupakan inovasi untuk mengisi kekosongan di sudut ruang perpustakaan (Gambar 1).

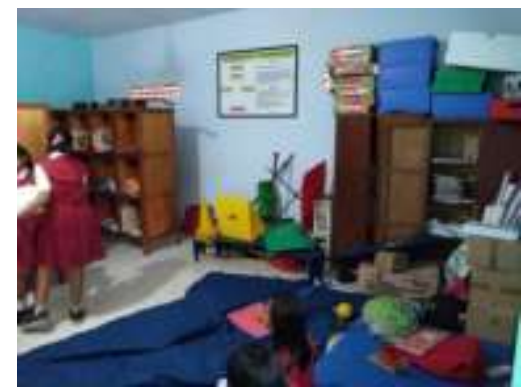

Gambar 1. Kondisi Awal Area Perpustakaan

Fasilitas pojok digital diharapkan dapat mengakomodir kebutuhan siswa dalam mengakses data dalam kegiatan penunjang pembelajaran. Fasilitas yang diberikan berupa personal computer dan tablet yang sudah diinstal dengan konten pembelajaran. Penyerahan serah terima fasilitas dilakukan langsung oleh tim dan dokumentasi dilakukan secara simbolis seperti tampak pada Gambar 2.

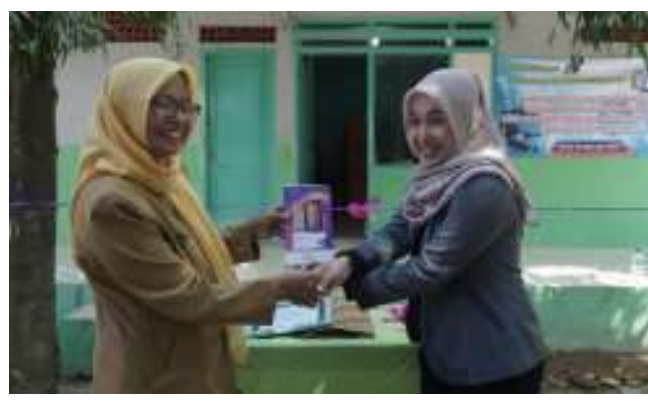

Gambar 2. Penyerahan Simbolis Gadget Antusiasme siswa diamati dengan menggunakan rubrik pengukuran motivasi belajar dan menunjukkan peningkatan sebesar 30\% (Gambar 3).

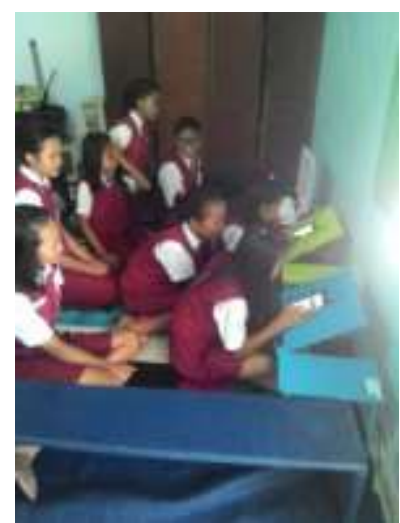

Gambar 3. Antusiasme Siswa

2. Pendampingan dari kegiatan penyusunan SOP manajemen operasional dalam pengelolaan pojok digital. Pendampingan juga dilakukan pada siswa dengan tujuan untuk memberikan sosialisasi dan pengarahan optimasi penggunaan fasilitas Pojok Digital dalam menunjang proses pembelajaran (Gambar 4).

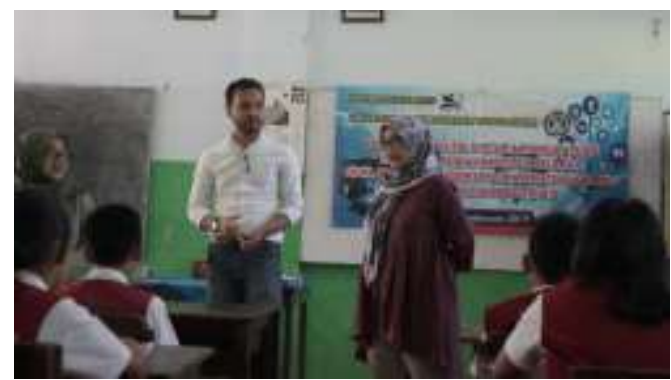

Gambar 4. Sosialisasi pada Siswa 
3. Pojok digital dirasa perlu sebagai upaya pengenalan literasi baru kepada siswa. Melalui hasil angket dan observasi, didapatkan peningkatan $30 \%$ pada motivasi belajar siswa dan $35 \%$ pada penguasaan literasi baru. Minimnya fasilitas pembelajaran juga menjadi urgensi pentingnya pojok digital di sekolah mitra. Akses informasi membutuhkan pendampingan guru mata pelajaran terkait, sehingga disusunlah SOP manajemen operasional, yang meliputi

4. Pemanfaatan Pojok Digital dalam proses pembelajaran

\section{ULASAN KARYA}

Kegiatan pengabdian masyarakat dengan sekolah mitra menjadi bagian penting dalam diseminasi ilmu pengetahuan serta perbaikan proses pembelajaran. Motivasi siswa dalam keterlibatan teknologi pada proses pembelajaran menjadi tolak ukur dalam kebermanfaatan program ini. Meskipun belum terlihat signifikan dalam hal pengukuran motivasi belajar siswa, namun dalam keberlanjutannya diyakini akan memberi pengaruh ke arah yang lebih baik.

Efektivitas penggunaan fasilitas ini baru terukur dalam angket dan observasi yang dilakukan oleh penulis dalam kajian terbatas, sehingga perlu dilakukan upaya untuk menunjang kontinuitas dari program ini di sekolah.

Hasil dari respon tersebut memberikan ruang dan tempat kepada siswa bahwa sebagai generasi Z, keterampilan dalam melakukan literasi menjadi kebutuhan yang penting. Hal ini senada dengan beberapa pengabdian yang dilakukan dengan prinsip memperkenalkan literasi informasi pada ibu-ibu tentang kegitan wirausaha dari internet [Khadijah, dkk. 2016].

Kendala awal yang dihadapi yaitu keraguan akan keberlanjutan program ini, apakah akan dapat dimanfaatkan dengan baik oleh siswa dan bagaimana jika dimanfaatkan untuk kepentingan entertainment. Namun, dengan adanya kegiatan pendampingan serta pendanaan dari DRPM Kemenristekdikti telah mampu mengubah paradigma negatif tersebut serta meningkatkan motivasi guru serta siswa di SD Negeri 2 Pujiharjo. Kendala dalam keterbatasan gadget dengan jumlah siswa juga menjadi kendala. Hal ini dikarenakan jumlah gadget yang diberikan kurang sebanding dengan jumlah siswa pengguna.

Upaya yang dilakukan yaitu memberikan pemahaman bahwa kegiatan ini di masa mendatang merupakan potensi sekolah untuk berkembang, seiring dengan keuletan serta ditunjang dengan peningkatan kualitas dalam manajemen operasional Pojok Digital.

\section{DAMPAK DAN MANFAAT KEGIATAN}

Dampak dari adanya Pojok Digital adalah antusiasme siswa serta guru dalam penggunaan fasilitas penunjang tersebut. Motivasi belajar mengalami kenaikan sebesar 30\%, yang teramati dari objek pada saat penggunaan gadget untuk penunjang pembelajaran pertama kalinya. Motivasi teramati dengan adanya perhatian, relevansi, kepercayaan diri dan kepuasan yang didapatkan siswa.

Sedangkan penguasaan literasi baru mengalami kenaikan sebesar $35 \%$ dari 
awal sebelum adanya program ini. Penguasaan literasi baru ditunjukkan melalui kemampuan siswa dalam searching, browsing, penggunaan informasi dalam pembelajaran, penggunaan gadget yang sesuai kaidah dan kebutuhan, serta aspek lain. Manfaat dari terselenggaranya program kemitraan masyarakat ini adalah memberikan fasilitas pendukung berupa Pojok Digital dalam proses pembelajaran. Penerapan skala terbatas dilakukan pada proses pembelajaran di kelas 5 dan kelas 6 .

\section{KESIMPULAN}

Target yang diharapkan dari program kemitraan masyarakat ini yaitu meningkatkan motivasi dan keterampilan siswa dalam mengenal literasi baru. Kegiatan dilanjutkan dengan pendampingan dan mendapat respon yang baik dari sekolah mitra. Hasil yang diperoleh yaitu sekolah mitra telah memiliki fasilitas Pojok Digital sebagai fasilitas penunjang yang berpotensi memberikan dampak yang positif.

\section{PENGHARGAAN}

Kegiatan program kemitraan masyarakat ini terselenggara atas hibah pendanaan dari KEMENRISTEKDIKTI. Ucapan terima kasih penulis khususnya Dirjen Riset dan Pengabdian Masyarakat (DRPM), LL DIKTI Wilayah VII Jawa Timur, Universitas Tribhuwana Tunggadewi, dan sekolah mitra, SD Negeri 2 Pujiharjo. Dengan segenap kerjasama dari pihak terkait serta sekolah mitra, kegiatan fasilitasi Pojok Digital ini dapat terlaksana dan berjalan dengan baik.

\section{DAFTAR PUSTAKA}

1. Ahmadi, F. (2017). Menyongsong Era Literasi Baru. Universitas Negeri Semarang. Gagasan [Online]. Available:

https://unnes.ac.id/gagasan/menyongs ong-era-literasi-baru/

2. Fitriani, Y; Ikhsan A.A. (2019). Literasi Era Revolusi Industri 4.0. presented at Seminar Nasional Bahasa dan Sastra. [Online]. Available: http://researchreport.umm.ac.id/index.php/SENASB ASA/article/viewFile/2592/2534

3. Intan, A. (2018). Era Revolusi Industri 4.0 Perlu Persiapkan literasi Data, Teknologi dan Sumber Daya Manusia. Direktorat Jenderal Pembelajaran dan Kemahasiswaan Kementrian Riset, Teknologi dan Pendidikan Tinggi. 17 Januari 2018 https://belmawa.ristekdikti.go.id/2018 /01/17/era-revolusi-industri-4-0perlu-persiapkan-literasi-datateknologi-dan-sumber-daya-manusia/

4. Khadijah, U. L. S., Diah S. R., Sukesih, dan Rully K., "Literasi Informasi Motivasi Berwirausaha Ibu Rumah Tangga Kelurahan Nagasari Kabupaten Karawang Barat" Jurnal Kajian Informasi dan Perpustakaan. 4. 2. (2016): 149-160.

5. S. Sholikha. (2015). Penerapan teknologi informasi dalam pendekatan saintifik pada mata pelajaran ekonomi, Pros. Semin. Nas. 9 Mei 2015, pp. 375-383, 2013. 